\title{
Autumnal aphid fauna on maize as an indicator of environmental changes
}

\section{Jesienna fauna mszyc na kukurydzy wskaźnikiem zmian środowiskowych}

\author{
Maria Ruszkowska*, Przemysław Strażyński
}

\section{Summary}

So far in Poland 7 aphid species developing only holocyclically have been observed on maize. Observations which were carried out in the Wielkopolska region in 2004-2012 revealed an occurrence of 5 aphid species. For the first time, in 2012, anholocyclic development of all the observed aphid species was recorded. Among them, new host races of Rhopalosiphum padi and Sipha maydis were isolated, as strict monophagous on maize. Their distinction was found in the studies conducted in environmental chamber conditions.

Key words: aphid fauna; host-races; maize

\section{Streszczenie}

W Polsce wykazano dotychczas 7 gatunków mszyc rozwijających się wyłącznie holocyklicznie na kukurydzy. Obserwacje prowadzone w Wielkopolsce, w okresie 2004-2012, wykazały obecność 5 gatunków. Po raz pierwszy w 2012 roku obserwowano rozwój anholocykliczny wszystkich stwierdzonych gatunków mszyc, spośród których wyodrębniono nowe rasy pokarmowe Rhopalosiphum padi i Sipha maydis, ścisłych monofagów na kukurydzy. Ich odrębność stwierdzono w badaniach ścisłych prowadzonych w kabinach klimatycznych.

Słowa kluczowe: fauna mszyc; rasy pokarmowe; kukurydza

Instytut Ochrony Roślin - Państwowy Instytut Badawczy

Zakład Entomologii

Władysława Węgorka 20, 60-318 Poznań

*corresponding author: M.Ruszkowska@iorpib.poznan.pl 


\section{Wstęp / Introduction}

Kukurydza pod względem powierzchni uprawy i globalnej produkcji zajmuje trzecie miejsce $\mathrm{w}$ świecie, po pszenicy i ryżu. W Polsce $\mathrm{w}$ ostatnich latach następuje szybki wzrost areału uprawy tej rośliny. Powierzchnia gruntów ornych przeznaczona pod uprawę samej tylko kukurydzy na ziarno zwiększyła się w 2012 roku w porównaniu do lat poprzednich, np. do roku 2011 aż o 63\% i wynosiła 543,8 tys. ha. Zbiory ziarna kukurydzy stanowiły wówczas ponad 4,0 $\mathrm{mln}$ ton, tj. o 1,6 mln ton (o 67\%) więcej niż w poprzednim roku (www.stat.gov.pl). Do najliczniejszych gatunków owadów zasiedlających kukurydzę należą: omacnica prosowianka, stonka kukurydziana, ploniarka zbożówka, mszyce: czeremchowozbożowa, różano-trawowa, zbożowa, rolnice, gatunki z rodziny sprężykowatych i poświętnikowatych oraz inne. Bereś (2011) wykazał na przykład, że w południowowschodniej Polsce kukurydza jest rośliną żywicielską dla 21 gatunków. Literatura światowa wskazuje na zasiedlanie kukurydzy przez 28 gatunków mszyc (Blackman i Eastop 2000). W Polsce dotychczas stwierdzono ich 8 (Szelegiewicz 1968). W krajach subtropikalnych najważniejszym szkodliwym gatunkiem mszycy na kukurydzy jest mszyca kukurydziana (Rhopalosiphum maidis Fitch, 1856) (Szelegiewicz 1968).

W zaleceniach integrowanych metod ochrony roślin (Integrated Pest Managment) próg szkodliwości mszyc na kukurydzy wynosi ponad 400 osobników na blaszce liściowej przed kwitnieniem (Pope i Tollefson 1998).

Większy areał uprawy kukurydzy oraz występujące okresowo wyższe temperatury umożliwiły owadom, a wśród nich szczególnie mszycom, zasiedlanie większych obszarów i stały się przyczyną zmian $\mathrm{w}$ ich biologii. Specyfika rozwojowa mszyc, dzięki odpowiedniemu wyposażeniu genetycznemu i enzymatycznemu, uruchamia mechanizmy adaptacji tych organizmów do nowych warunków środowiskowych. Do ważniejszych czynników wpływających na alternatywny rozwój mszyc można włączyć jakość pokarmową roślin żywicielskich, odpowiedni przebieg temperatur oraz fotoperiod. Możliwość powstawania nowych form rozwojowych i ras pokarmowych $\mathrm{w}$ zmieniającym się środowisku ma znaczenie w zrozumieniu biologii ewolucyjnej, a w praktyce także dla rolnictwa (Dixon i Glen 1971; Dixon 1998; Ruszkowska 2002, 2007). Powstawanie form anholocyklicznych w uprawach zbóż uwarunkowane jest wystąpieniem odpowiednio wyższych temperatur wiosną i wczesnym latem, kiedy średnia dobowa osiąga wartość $\geq 25^{\circ} \mathrm{C}$. Na zbożach, łącznie z kukurydzą, stwierdzono dotychczas nowe, anholocykliczne formy rozwojowe mszyc: Rhopalosiphum padi (Linnaeus, 1758), Metopolophium dirhodum (Walker, 1849) i Sitobion avenae (Fabricius, 1775). Mają one duże znaczenie $\mathrm{w}$ ochronie roślin, ponieważ są jedynymi wektorami wirusów żółtej karłowatości jęczmienia, najgroźniejszej choroby wirusowej zbóż (Barley yellow dwarf virus, BYDY) (Jeżewska i wsp. 2010).

Dotychczasowe badania wykazały, że kukurydza może mieć znaczącą rolę $\mathrm{w}$ integrowanej ochronie zbóż przed BYDV. Stwierdzono, że sąsiedztwo upraw tej rośliny ze zbożami może być naturalną metodą ograniczającą roz- przestrzenianie się infekcyjnych mszyc. Kukurydza jako roślina pokarmowa bardziej atrakcyjna do żerowania, w okresie przedżniwnym blokuje przelot mszyc na trawy dziko rosnące - źródło pobierania wirusów, a w okresie wschodów ozimin zbóż, mszyce wolne od wirusów, wracają z kukurydzy na oziminy (Ruszkowska i wsp. 2012).

Celem prowadzonych badań było określenie jesiennej fauny mszyc na kukurydzy, stwierdzenie preferencji pokarmowych mszyc $R$. padi i Sipha (Rungsia) maydis Passerini, 1860 mających do wyboru zasiedlanie roślin jęczmienia ozimego i kukurydzy oraz możliwości i warunki rozwoju nowych ras pokarmowych.

\section{Materiały i metody / Materials and methods}

Badania jesiennej fauny mszyc na plantacjach kukurydzy prowadzono na terenie Wielkopolski (gminy: Kiszkowo, Sieraków, Ostrzeszów, Szamocin) w okresie od 1. września do 20. grudnia, w latach 2009-2012. Mszyce zbierano cotygodniowo, bezpośrednio z roślin, w uprawach produkcyjnych. Określano liczebność mszyc uskrzydlonych i bezskrzydłych na 100 roślinach. Trudniejsze do oznaczenia gatunki identyfikowano w laboratorium pod mikroskopem. Jesienne formy mszyc: $R$. padi, $R$. maidis, M. dirhodum, S. avenae i $S$. maydis po osiem kolonii, przeniesiono do kabiny klimatycznej, gdzie hodowano je dalej na roślinach kukurydzy rosnących $\mathrm{w}$ doniczkach celem potwierdzenia ich anholocyklicznego rozwoju. Mszyce hodowano przez okres rozwoju ponad 20 pokoleń. Szczególnie ścisłym obserwacjom mającym ukazać preferencje pokarmowe mszyc poddano R. padi i $S$. maydis. Przez cały okres badań mszyce miały dostęp do roślin jęczmienia ozimego i pszenicy ozimej. Zastosowano „testy z wyboru" - mszyce mogły wybierać roślinę żywicielską $\mathrm{i}$ „testy z przymusu” - mszyce nie miały wyboru rośliny żywicielskiej. W czasie prowadzenia hodowli w kabinie panowały stałe warunki klimatyczne: temperatura $20^{\circ} \mathrm{C}$, długość dnia 12 godzin i wilgotność $60 \%$.

\section{Wyniki i dyskusja / Results and discussion}

W jesiennych obserwacjach na kukurydzy stwierdzono ogółem 1719 mszyc, spośród których wyodrębniono 5 gatunków mszyc (tab. 1,2). Najliczniejszym gatunkiem była mszyca $R$. padi, a mniej licznymi: $S$. maydis, $R$. maidis, M. dirhodum, S. avenae. Tylko wśród osobników $R$. padi stwierdzono występowanie morf uskrzydlonych. Mszyce $S$. maydis zasiedlały kukurydzę mało licznie tworząc kolonie, w których występowało przeciętnie od 1 do 3 mszyc.

Wszystkie mszyce hodowane w kabinie klimatycznej rozwijały się na kukurydzy anholocyklicznie nie zasiedlając innych zbóż. Permanentną partenogenezę potwierdzono przez dalsze obserwacje rozwoju. W ciągu 20 generacji nie powstawały formy seksualne.

Mszyce $R$. padi i $S$. maydis, których rozwój miał wykazać wystąpienie preferencji pokarmowych do zasiedlania różnych gatunków zbóż, mając do wyboru pszenicę, jęczmień i kukurydzę, zasiedlały tylko kukurydzę (test 
Tabela 1. Struktura fauny jesiennych populacji mszyc na kukurydzy w okresie od początku września do końca drugiej dekady grudnia w latach 2009-2012 (wartości średnie, sumarycznie ze 100 roślin)

Table 1. Autumnal population structure of aphids on maize during early September until the second decade of December of the years 2009-2012 (mean values, in total from 100 plants)

\begin{tabular}{l|c|c|c|c}
\hline \multicolumn{1}{c|}{$\begin{array}{c}\text { Gatunek mszycy } \\
\text { Aphid species }\end{array}$} & $\begin{array}{c}\text { Liczba kolonii } \\
\text { Number } \\
\text { of colonies }\end{array}$ & $\begin{array}{c}\text { Liczba mszyc } \\
\text { uskrzydlonych } \\
\text { Number } \\
\text { of winged aphids }\end{array}$ & $\begin{array}{c}\text { Liczba mszyc } \\
\text { bezskrzydłych } \\
\text { Number of wingless aphids }\end{array}$ & $\begin{array}{c}\text { Ogółem } \\
\text { Total }\end{array}$ \\
\hline Rhopalosiphum padi subsp. maidis* & 8 & 4 & 1620 & 1624 \\
\hline Sipha (Rungsia) maydis subsp. maidis* & 21 & 0 & 58 & 58 \\
\hline Rhopalosiphum maidis & 8 & 0 & 9 & 21 \\
\hline Metopolophium dirhodum & 2 & 0 & 7 & 9 \\
\hline Sitobion avenae & 2 & 0 & Suma - In total & 1719 \\
\hline
\end{tabular}

*stwierdzone po raz pierwszy w Polsce formy anholocykliczne, nowe w świecie rasy pokarmowe, zdolne do życia tylko na kukurydzy - first record of anholocyclic forms in Poland, aphid nutrient races new for the world, viable only on maize

Tabela 2. Fauna mszyc na kukurydzy: na świecie, w Polsce i w Wielkopolsce, z wyodrębnieniem nowych ras pokarmowych gatunków rozwijających się jesienią anholocyklicznie

Table 2. Aphid fauna on maize: in the world, in Poland and in Wielkopolska with the separation of the new nutrient races of species developing permanently parthenogeneticly during the autumn

\begin{tabular}{|c|c|c|}
\hline $\begin{array}{l}\text { Światowa fauna mszyc } \\
\text { Global aphid fauna } \\
\text { (Blackman i Eastop 2000) }\end{array}$ & $\begin{array}{l}\text { Polska fauna mszyc } \\
\text { Polish aphid fauna } \\
\text { (Szelegiewicz 1968) }\end{array}$ & $\begin{array}{l}\text { Wielkopolska fauna mszyc } \\
\text { (zbiory własne 2009-2012) } \\
\text { Wielkopolska aphid fauna } \\
\text { (own collection 2009-2012) }\end{array}$ \\
\hline Anoecia corni (Fabricius, 1775) & - & - \\
\hline Aphis armoraciae Cowen ex Gilette \& Baker, 1895 & - & - \\
\hline A. craccivora Koch, 1854 & - & - \\
\hline A. fabae Scopoli, 1763 & A. fabae & - \\
\hline A. gossypi Gloger, 1877 & - & - \\
\hline Colopha ulmicola (Fitach, 1859) & - & - \\
\hline Geoida lucifuga (Zehntner, 1897) & - & - \\
\hline G. urticularia (Passerini, 1856) & - & - \\
\hline Hysteroneura setariae (Thomas, 1878) & - & - \\
\hline Macrosiphum euphorbiae (Thomas, 1878) & M. euphorbiae & - \\
\hline Melanaphis formosana (Takahashi, 1921) & - & - \\
\hline M. sorghi (Theobald, 1904) & - & - \\
\hline Metopolophium dirhodum (Walker, 1849) & M. dirhodum & M. dirhodum \\
\hline M. festucae subsp. cerealium Stroyan, 1982 a & - & - \\
\hline M. obtusirostris David, Narayanan \& Rajasingh, 1971 b & - & - \\
\hline M. persicae (Sulzer, 1776) & - & - \\
\hline Pemphigus sp. & - & - \\
\hline Rhopalosiphum maidis (Fitch, 1856) & R. maidis & R. maidis \\
\hline R. padi (Linnaeus, 1758) & R.padi & - \\
\hline- & - & R. padi. subsp. maydis* \\
\hline Rhopalosiphoninus indicus L.K. Gosh, 1986 & - & - \\
\hline Schizaphis graminum (Rondani, (1847) 1852) & - & - \\
\hline Sipha flava (Forbes, 1884) & - & - \\
\hline S. (Rungsia) maydis Passerini, 1860 & S. (Rungsia) maydis & - \\
\hline- & - & S. (Rungsia) maydis subsp. maidis* \\
\hline Sitobion africanum (Hille Ris Lambert, 1954) & - & - \\
\hline S. avenae (Fabricius, 1775) & S. avenae & S. avenae \\
\hline S. howlandae (Eastop, 1959) & - & - \\
\hline S. miscanthi (Takahashi, 1921) & - & - \\
\hline Tetraneura radicicola Strand, 1929 & - & - \\
\hline T. ulmi (Linnaeus, 1758) & T. ulmi & - \\
\hline
\end{tabular}

*stwierdzone po raz pierwszy w Polsce formy anholocykliczne, nowe dla nauki rasy pokarmowe, zdolne do życia tylko na kukurydzy - first record of anholocyclic forms in Poland, aphid nutrient races new for the science, viable only on maize 
z wyboru). Osobniki nakładane z kukurydzy na jęczmień i pszenicę nie rozwijały się i ginęły (test $z$ przymusu). Hodowane populacje przez okres 20 pokoleń nie były zdolne do powrotu do formy holocyklicznej, mogącej zasiedlać zarówno jęczmień ozimy, jak i kukurydzę. Dla wyodrębnienia nowych form do nazwy gatunku dodano „subsp. maydis”, tj. człon nazwy sugerujący pochodzenie tylko z kukurydzy.

Gatunki mszyc $R$. padi i $S$. maydis, stwierdzone jesienią na kukurydzy można uznać za podgatunki gatunków politypowych, tzn. zróżnicowanych wewnątrzgatunkowo. Szelegiewicz (1968) wykazał występowanie podgatunku holocyklicznego oraz jednodomnego S. (Rungsia) maydis graminis i w jego obrębie wyodrębnił podgatunek nominatywny żyjący wyłącznie na kukurydzy, ale tylko w zlewisku Morza Śródziemnego. Wydaje się naukowo uzasadnione zastosowanie trójnominalnej nomenklatury w określeniu stwierdzonych na kukurydzy podgatunków nominatywnych $R$. padi subsp. maydis i $S$. maydis subsp. maydis albo $R$. padi maydis i $S$. maydis maydis.

W Argentynie gatunek S. (Rungsia) maydis wykazano jako nowego szkodnika zbóż, traw uprawnych i dzikich, który jednak nigdy nie zasiedlał kukurydzy (Corrales i wsp. 2007). Obserwacje te potwierdzają występowanie odrębnych ras w obrębie tego gatunku. S. (Rungsia) maydis jest również uznawanym wskaźnikiem suszy. Rejestracja ekspansji terytorialnej tych mszyc w USA, stwierdzonych po raz pierwszy w Georgii w roku 2009 i Kalifornii w 2011 roku, została uznana za efekt postępu- jącej suszy (Halbert 2013). Stwierdzenie po raz pierwszy w Wielkopolsce występowania na kukurydzy w okresie jesieni anholocyklicznych form $S$. (Rungsia) maydis subsp. maydis może sugerować postępującą suszę i wystąpienie wyższych od dotychczasowych średnich temperatur w regionie.

\section{Wnioski / Conclusions}

1. Wykazano po raz pierwszy w Polsce anholocykliczny rozwój mszycy $S$. (Rungsia) maydis.

2. Wszystkie gatunki mszyc stwierdzone na kukurydzy w okresie jesieni były formami anholocyklicznymi. Pojawienie się form anholocyklicznych mszyc na kukurydzy świadczy o wystąpieniu wyższych od dotychczasowych temperatur wiosną, latem i jesienią.

3. Mszyce $R$. padi i $S$. maidis notowane na kukurydzy w okresie jesieni były ścisłymi monofagami na kukurydzy i zostały uznane jako nowe dla wiedzy podgatunki nominatywne i nazwane $R$. padi subsp. padi i $S$. maydis subsp. maidis.

4. Stwierdzenie ścisłych monofagów na kukurydzy i uznanie ich jako nowych podgatunków tylko na podstawie testów biologicznych, w obliczu współczesnych metod badawczych, wymaga uzupełnienia testami na poziomie molekularnym. Uzyskany materiał biologiczny jest zakonserwowany i będzie poddawany takim analizom.

\section{Literatura / References}

Bereś P.K. 2011. Mniej znane gatunki z gromady owadów (Insecta) zasiedlające rośliny kukurydzy (Zea mays L.) w południowowschodniej Polsce w latach 2005-2010. [Less known pests found on maize (Zea mays L.) in South-East Poland in 2005-2010]. Progress in Plant Protection/Postępy w Ochronie Roślin 51 (1): 21-27.

Blackman R.L., Eastop V.F. 2000. Aphids on the World's Crops. An Identification and Information Guide. 2nd ed. J. Wiley and Sons, $466 \mathrm{pp}$.

Corrales C.E., Castro A.M., Ricci M., Dixon A.F. 2007. Sipha maydis: distribution and host range of a new aphid pest of winter cereals in Argentina. Journal of Economic Entomology 100 (6): 1781-1788.

Dixon A.F.G., Glen D.M. 1971. Morph determination in the bird-cherry oat aphid, Rhopalosiphum padi L. Annals of Applied Biology 69: $11-21$.

Dixon A.F.G. 1998. Aphid Ecology. 2nd ed. Chapman and Hall, 300 pp.

Główny Urząd Statystyczny, Portal Informacyjny [online]. www.stat.gov.pl [dostęp: 01.10.2014]

Halbert S.E., Miller G.L., Ames L.M. 2013. The genus Sipha Passerini (Hemiptera: Aphididae) in North America. Insecta Mundi. A Journal of World Insect Systematics 0326: 1-6.

Jeżewska M., Cajza M., Buchowska-Ruszkowska M. 2010. Monitoring i diagnostyka molekularna wirusów zbóż. s. 157-180. W: „Ograniczanie strat $\mathrm{w}$ plonach roślin uprawnych z zachowaniem bezpieczeństwa żywności” (D. Sosnowska, red.). Instytut Ochrony Roślin - Państwowy Instytut Badawczy, Poznań, 284 ss.

Pope R., Tollefson J. 1998. Be aware of corn leaf aphids. Integrated Crop Management IC 480 (21): 159-161.

Ruszkowska M. 2002. Przekształcenia cyklicznej partenogenezy mszycy Rhopalosiphum padi (L.) (Homoptera: Aphidoidea) - znaczenie zjawiska w adaptacji środowiskowej. Rozprawy Naukowe Instytutu Ochrony Roślin 8, 63 ss.

Ruszkowska M. 2007. Across the transformation life cycle of Rhopalosiphum padi (L.) (Homoptera: Aphidoidea): coevolution with temperature. Rozprawy Naukowe Instytutu Ochrony Roślin 15, 60 pp.

Ruszkowska M., Strażyński P., Wachowiak H. 2012. Preferencje pokarmowe mszyc na wybranych gatunkach zbóż. [Aphid host plant preferences in relation to the selected species of cereals]. Progress in Plant Protection/Postępy w Ochronie Roślin 52 (4): $849-853$.

Szelegiewicz H. 1968. Katalog fauny Polski. Mszyce. Aphidodea. PWN, Warszawa, 307 ss. 